\title{
O crime de Leopoldina: relações familiares e resistência em um contexto de escravidão (Cachoeira, século XIX)
}

The crime of Leopoldina: family relationships and resistance in a context of slavery (Cachoeira do Sul, XIX century)

\author{
Paulo Roberto Staudt Moreira* \\ staudt@unisinos.br \\ Marina Camilo Haack** \\ marina_haack@hotmail.com
}

\begin{abstract}
Resumo: Nos últimos anos a historiografia brasileira sobre o escravismo foi uma das que mais cresceu. Entre as temáticas tratadas, destaca-se a família escrava, que se já não precisa mais ter comprovada a sua existência, ainda carece de investigações quanto aos seus significados e estruturas. Este artigo pretende abordar a família escrava tomando como fonte privilegiada um documento judiciário. Trata-se da investigação de um filicídio cometido pela escrava Leopoldina, em 1874, na cidade de Cachoeira, localizada no Brasil meridional. Com a análise deste processo crime podemos tentar reconstruir alguns aspectos da família escrava e das vivências de Leopoldina, tomando como base uma bibliografia que tenta compreender os nuances das famílias constituídas dentro do cativeiro. Aspectos como liberdade, violência, resistência, negociações e cor, serão contemplados.

Palavras-chaves: família escrava, resistência, Cachoeira/RS
\end{abstract}

Abstract: In recent years the Brazilian historiography of slavery was one of the fastest growing. Among the discussed issues, there is the slave family, which no longer need to have proven its existence, still needs investigation as to their meanings and structures. This article aims to address the slave family taking as a prime source a judicial document. This is the investigation of a filicide committed by the slave Leopoldina in 1874 in the city of Cachoeira, located in southern Brazil. With the analysis of this criminal case we can try to reconstruct some aspects of the slave family and Leopoldina experiences, based on a bibliography that tries to understand the nuances of families constituted in captivity. Aspects such as freedom, violence, resistance, negotiations and color, will be affected.

Keywords: family relationships, resistance, Cachoeira/RS 
Ao historiador, curioso e incansável em sua busca por carne humana, segundo Bloch (2001), ou pela reconstrução do passado e dos mortos, como diria Certeau (1982), resta a tentativa constante de compreensão de um tempo e de indivíduos que jamais poderão ser revisitados em sua plenitude. Tratar destes indivíduos, principalmente no caso dos escravos ou da população de cor do período colonial e imperial brasileiro, constitui uma verdadeira empreitada, e por isso a historiografia tentou durante muito tempo "silenciar" suas ações, ou tratá-las de forma fútil. Não puderam, contudo, calar totalmente o que estes indivíduos gritaram de diversas maneiras, fosse em depoimentos nos processos criminais, jornais, organizações, fugas ou em suas mais diversas práticas religiosas.

Atualmente, o historiador tenta montar partes deste quebra-cabeça que forma o período que vigorou a escravidão no Brasil, valorizando sujeitos históricos que conviveram em suas mais diversas convicções culturais. O estudo das populações escravizadas pode se tornar mais complexo ainda do que se imagina. Robert Slenes (1992, p. 49) nos chama atenção para tal problema, enquanto pensava sobre as plurais características dos africanos trazidos para o Brasil. Segundo ele, se a África e os africanos permaneceram cobertos e desconhecidos pela elite brasileira, o fizeram "parte porque dos escravos, para defender-se de seus senhores, fizeram-se mestres da dissimulação".

Nos últimos anos a historiografia sobre o escravismo foi uma das que mais cresceu no Brasil, principalmente impulsionada pelas pesquisas localizadas nos Programas de Pós-graduação. Entre as temáticas tratadas, destaca-se a família ${ }^{1}$ escrava, que se já não precisa mais ter comprovada a sua existência, ainda carece de investigações quanto aos seus significados e estruturas. Esse artigo pretende abordar a família escrava tomando como fonte privilegiada um documento judiciário. Trata-se da investigação de um filicídio cometido pela escrava Leopoldina, em 1874, na cidade de Cachoeira, localizada no Brasil meridional ${ }^{2}$. Com a análise desse processo crime podemos tentar reconstruir alguns aspectos da família escrava e das vivências de Leopoldina, tomando como base uma bibliografia que tenta compreender as nuances das famílias constituídas dentro do cativeiro. Aspectos como liberdade, violência, resistência, negociações e cor, serão contemplados.

Pensando em se tratar destes indivíduos escravizados, tão múltiplos entre si e mestres da dissimulação, é que nossa jornada inicia. É farejando o caso de Leopoldina que convidamos os leitores para seguirem nossas reflexões, para tanto, vamos começar conhecendo o cenário em que Leopoldina viveu, estabeleceu laços, sofreu as agruras do cativeiro e pensou e planejou o que talvez tenha sido a decisão mais difícil em sua vida.

\section{O cenário}

A vila de Cachoeira, assim considerada desde 1819, teve sua ocupação firmada a partir da segunda metade do século XVIII, partindo do interesse da Coroa de que as terras devolutas da porção sul da colônia tivessem sua posse assegurada com relação ao vizinho espanhol. Logo, gentes diversas foram ocupando esse espaço, que já conhecia a presença de população nativa, não sendo raros os relatos de viajantes que deram ênfase para a presença indígena. Configurava-se naquela etapa da ocupação um cenário dividido entre campo e floresta, onde o rio Jacuí representou um poderoso impulso econômico para a região. (FORTES \& WAG-

\footnotetext{
${ }^{1}$ Família: "Núcleo social de pessoas unidas por laços afetivos, que geralmente compartilham o mesmo espaço e mantém entre si relação solidária". Grande Dicionário Houaiss da Língua Portuguesa. http://houaiss.uol.com.br/ - acessado em 10.05.2016.

${ }^{2}$ APERS, Cível e crime. N 3185, M 9, E 56, Ano de 1874; processo de Apelação N 3181, M 9, E 56, Ano 1874, ambos Cachoeira.
} 
NER, 1963; FAGUNDES, 2009; SÔNEGO, 2011; OLIVEIRA, 2013).

A partir da segunda metade do século XIX, Cachoeira conheceu outros dois fluxos imigratórios, em 1857 os alemães e em 1877 os italianos ali se instalaram, configurando, assim, um espaço pluriétnico, composto por europeus, indígenas, negros escravizados e libertos e os livres de cor.

Em 1814 Cachoeira tinha uma população de 8.225 habitantes, uma das maiores da província no período, distribuída em 4.576 brancos (56\%), 2.622 escravizados (32\%), 425 indígenas (5\%), 398 livres $(5 \%)$ e recém-nascidos $204(2 \%)^{3}$. Vale ressaltar, a título de comparação, que ainda segundo o censo de 1814, a capital da capitania, a Freguesia de Nossa Senhora da Madre de Deus de Porto Alegre tinha 6.111 habitantes, dos quais 2.746 eram livres e brancos de ambos os sexos e 2.312 eram homens e mulheres escravizados, representando aproximadamente $40 \%$ da população sendo escrava, um porcentual maior do que em Cachoeira, para o mesmo período. Deve-se considerar, ainda, que Cachoeira só recebeu o título de vila em 1818 e que Porto Alegre estava passando por um período de crescimento populacional, mas em números gerais era Cachoeira que contava com um contingente populacional maior. ${ }^{4}$

No censo de 1859 Cachoeira apresentava um número menor de habitantes, 5.169 indivíduos, certamente justificado pela criação do município de Santa Maria (lei $n^{\circ} 400$, de 16.12.1857), mas em uma análise por porcentagem apresentava ainda uma forte presença de escravizados: livres 3.456 (67\%), cativos 1.628 (31\%) e libertos $85(2 \%){ }^{5}$
Embora este segundo censo não apresente a classificação de indígenas, estes provavelmente estão inclusos na categoria de "livres". Para se ter acesso a uma quantificação mais exata desta população, seria necessário fazer uma análise dos registros paroquiais de $\mathrm{Ca}$ choeira, identificando a presença destes indivíduos a partir da designação de cor ou etnia nessas fontes eclesiásticas.

Ainda sobre a presença da população indígena naquele cenário, o naturalista Auguste Saint-Hilaire, em sua passagem por Cachoeira, em 1821, anotou em seu diário que: "Entre a vila e o rio, sobre o declive da colina, as miseráveis palhoças, separadas umas das outras, cuja reunião toma o nome de Aldeia. Estas choupanas são habitadas por índios, que vieram da aldeia de São Nicolau". (SAINT-HILAIRE, in OLIVEIRA, 2013, p. $58)$.

O vice-presidente da Província de São Pedro, Luiz Alves Leite de Oliveira Bello, em 1856, em seu relatório, destacou como a vila era favorecida por sua posição estratégica às margens do rio Jacuí do ponto de vista comercial: "Esta Vila está muito bem situada na margem esquerda do majestoso Jacuí. [...] Sem contestação, é a Vila da Cachoeira uma das povoações mais bonitas da Província". (FAGUNDES, 2009, p. 15-16).

Em contraponto, Conde d'Eu, de passagem por Cachoeira durante a Guerra do Paraguai, em 1865, teve uma impressão bem mais negativa da vila, talvez por sua referência ter sido a Corte ou pelo desgaste psicológico da guerra: "Como Rio Pardo, Cachoeira fica num alto; mas, embora tenha título de cidade, não passa de uma aldeia". (SCHUH \& CARLOS, in OLIVEIRA, 2013, p. 59).

\footnotetext{
${ }^{3}$ Fonte: Mapa Estatístico da Província de São Pedro de 1814 (CARDOSO, in FAGUNDES, 2009, p. 48).

${ }^{4}$ FUNDAÇÃO DE ECONOMIA E ESTATÍSTICA, 1981, p. 50.

${ }^{5}$ Fonte: Mapa Estatístico da população da província classificada por idades, sexos, estados e condição com o resumo do total de livres, libertos, e escravos (FAGUNDES, 2009, p. 49).
} 
Se as passagens de Saint-Hilaire e Conde d'Eu fazem uma representação sobre esta vila partindo de um olhar europeizante, podemos utilizar o caso da china Antônia Maria para repensar as experiências da população indígena em Cachoeira. No dia 19 de novembro de 1847 foi oficializada no cartório da vila de Cachoeira uma doação para Verônica Antônia, de "um terreno na Aldeia, com um rancho de palha e todas as mais benfeitorias que existam dentro dos cercados no lugar desta aldeia". Essa doação foi feita em função dos cuidados que Verônica prestara a Antônia no período em que uma moléstia lhe acometera. China era um designativo que apontava a origem indígena destes indivíduos. (GUTERRES, 2013) Mas o que gostaríamos de chamar a atenção nesse caso, é que as miseráveis palhoças vistas por Saint-Hilaire e que compunham a aldeia de Cachoeira, certamente não configuravam as simples aglomeração de populações pobres que nossos viajantes identificaram. A reciprocidade identificada nesse vestígio documental cartorial nos permite visualizar interrelações e sociabilidades, que mostram que estas populações estavam longe de serem subsumidas a anomia e a subalternização sócioracial ${ }^{6}$. Aliás, pesquisas nos arquivos locais de Cachoeira tem nos permitido visualizar inter-relações entre indígenas e escravizados. Em 17.06.1820 foi batizada a africana Isabel Conga, de apenas 10 anos, escravizada por João Francisco da Silva. Seus padrinhos foram o índio Antônio e a china Rafaela. Em $1^{\circ} .11 .1853$ casaram na Igreja de Nossa Senhora da Conceição da Cachoeira José Alexandre da Silva (natural da cidade de Rio Pardo, de nação Guarani) e a preta Sofia (escrava de Pacífico Pereira Fortes) ${ }^{7}$. Ou seja, parentescos diversos entrecruzavam estas cate- gorias sócio-étnico-raciais, gerando contatos, atritos e solidariedades.

Segundo Renato Pinto Venâncio (2012, p. 218), a população escrava na província do Rio Grande de São Pedro, já nas décadas finais da escravidão, ainda apresentava um percentual surpreendente, se comparada com outras províncias, sendo entre os baianos $12,4 \%$, pernambucanos $12,8 \%$, mineiros $15,9 \%$, gaúchos 21,3\% e São Paulo 20,4\%. Segundo esse censo de 1872, que possui uma maior probabilidade de exatidão em razão da lei de 28.09.1871 e a obrigação dos senhores matricularem seus cativos, Cachoeira tinha cerca de $18 \%$ da sua população ainda escravizada, com aproximadamente 1.236 cativos. (SÔNEGO, 2011, p. 37) Entretanto, segundo os dados apresentados por ARAÚJO (2011, p. 6), o número de escravos de Cachoeira seria de 2.326 , conformando $19,79 \%$ da população total de 11.756 habitantes.

Esta população escravizada estava distribuída, principalmente, em pequenas e médias escravarias. Investigando os inventários post-mortem daquela vila, Sônego (2011, p. 50) encontrou apenas 2 defuntos com 19 ou mais escravos arrolados, sendo a maioria das escravarias $(76,66 \%)$ composta de 1 a 5 indivíduos. A economia baseava-se em uma produção agro-pecuária, sendo a maioria das propriedades pluriocupacionais, mesclando criação de gado e lavoura.

É neste cenário, mais especificamente no terceiro distrito da cidade, no Capão da Cutia, que em 1874 um longo embate judiciário será travado: trata-se do filicídio cometido por Leopoldina.

\footnotetext{
${ }^{6}$ Arquivo Público do Estado do Rio Grande do Sul, $5^{\circ}$ livro de registros cartoriais, Cachoeira, $2^{\circ}$ tabelionato da Vila, $1847-1852$, folha 4 verso.

${ }^{7}$ Arquivo da Cúria Metropolitana de Cachoeira do Sul, Livro $1^{\circ}$ de Batismos de Escravos (1799/1842); Livro de Casamentos de Cachoeira, $n^{\circ} 4$, 1849 1881 , folha $34 r$.
} 


\section{"É quando cresceu meu pasmo ouvir} dela própria confissão de ser autora do infanticídio"

No dia 31 de dezembro de 1873, véspera de ano novo, na propriedade de Evaristo Antônio de Moraes, seus escravos já estavam trabalhando na roça logo cedo pela manhã. Paulino, que tinha em torno de 13 para 14 anos, ficou encarregado de ajudar seus companheiros na roça do Capão da Cutia. A mãe de Paulino, Leopoldina, estava incumbida de realizar os serviços domésticos, saindo para a lavagem de roupa. Mais tarde, no mesmo dia, Leopoldina chamou seu filho, alegando que o fazia a mando de seu senhor, e lhe propôs que ambos, para livrarem-se do cativeiro, tomassem a saída da morte. O planejado era que Leopoldina degolasse Paulino com uma faca, sendo essa emprestada de "um irmãozinho seu", e logo em seguida acabaria com sua própria vida, enforcando-se em uma árvore. Segundo Leopoldina, Paulino não havia resistido ao seu plano, pois ambos eram muito maltratados pela esposa de seu senhor.

O uso da faca devia ser habitual para aquela trabalhadora escravizada, cotidianamente manejada no abate de pequenos animais e nas lidas da cozinha senhorial. Para Leopoldina também não devia faltar força física, acostumada que estava ao duro esforço corporal despendido no trabalho doméstico. Mãos calejadas e fortes devem ter segurado a faca assassina e cortado habilmente a jugular do menino Paulino. Sangue e lágrimas devem ter se misturado naquela cena campestre que teve apenas dois solitários atores, um filho sacrificado e sua mãe assassina.
Após degolar seu filho, Leopoldina tentou enforcar-se em uma árvore, porém diz ela que a corda se partiu e aparentemente tal incidente provocou uma mudança em seus planos. Ela correu nua para a casa de Bento Antônio de Moraes $^{8}$ e disse que malfeitores teriam capturado seu filho e que durante a luta perdera o seu vestido. Já para a irmã de Bento, ela teria implorado que a comprasse, pois sua mãe seria libertada em breve e ela não queria ver-se sozinha em cativeiro. Provavelmente Leopoldina via nesta mulher, um membro da própria família senhorial, um refúgio para os maus tratos de sua senhora. Tão logo a equipe de busca encontra Paulino sem vida e com o vestido de Leopoldina sobre o corpo, ela admite ter sido a praticante do homicídio e o caso vai a julgamento.

\section{$* * *$}

O uso dos processos crimes, dentro da historiografia brasileira, trouxe luz a uma série de experiências sociais, dando voz aos réus, vítimas e testemunhas do mundo colonial e imperial ${ }^{9}$, sobretudo da população de cor e escrava. Não somos ingênuos a ponto de acreditar que a realidade ocorreu tal qual o depoimento desses indivíduos nos informa, mas sabemos que, apesar do filtro dos escrivães, os testemunhos destes sujeitos expunham suas motivações para determinados atos, apresentavam suas ideias de "justo" e "injusto", o aceitável e o inaceitável dentro do cativeiro ${ }^{10}$. Lidos com atenção, os documentos judiciários são minas de dados involuntários (GINZBURG, 1991), trazendo vestígios de sentimentos e motivações que nos permitem uma aproximação do cotidiano daquela sociedade escravista oitocentista.

\footnotetext{
${ }^{8}$ Sobrinho do dito Evaristo.

${ }^{9}$ Se antes a historiografia tratava a escravidão a partir de uma perspectiva de "coisificação" dos cativos, ou como o primeiro "ato humano" do escravo sendo o crime, sabemos hoje o suficiente para identificar nestas ações não somente consciência, mas formas constantes de resistência dentro do sistema escravista. Lançar esse olhar sobre as fontes é, também, superar essas antigas afirmações que não viam no indivíduo escravizado qualquer resquício de humanidade.

${ }^{10}$ Sidney Chalhoub em "Visões da Liberdade" fez uma análise exaustiva do uso dos processos criminais como fonte para o entendimento das décadas finais da escravidão na Corte, trazendo exemplos das ideias de liberdade dos próprios escravos. (CHALHOUB, 1990).
} 
O caso do escravo charqueador Benedito, que assassinou o capataz Cipriano em 1849, quando trabalhava na charqueada de seu senhor, na vila de São Jerônimo, também localizada nas margens do rio Jacui, pode nos servir de exemplo. Se auto-referenciando como mina-nagô, o africano Benedito labutava há muitas horas sem descanso, abatendo gado e produzindo mantas de charque, e quando foi lavar-se à beira do rio, o imprevidente capataz o castigou, segundo ele, injustamente. Benedito justificou que:

\section{[...] pois que de seus senhores e de mui- tos capatazes com quem tinha servido, nunca apanhou, porque era seu costume respeitar e obedecer a todos, cumprindo com os seus deveres, e a esta resposta o capataz o mandara amarrar, e que nesta ordem ele réu temendo um rigoroso cas- tigo, sem ter cometido delito, foi que deu lugar a ele réu lançar mão da faca, co- berto de cólera, precipitou-se sobre o Capataz, e the deu muitas facadas. (MOREIRA, 2008, p. 171)}

Para Benedito, que sempre realizou bem seu serviço e que nunca havia sido castigado antes, o capataz se precipitou na punição, visto que aquele trabalhador escravizado apenas estava lavando seus pés, já muito sujos pelo sangue dos bois, proveniente de seu trabalho na charqueada. Sentimentos de honra e masculinidade - no caso alimentados principalmente pelo orgulho do trabalho especializado bem feito -, também moviam as ações dos trabalhadores escravizados. Documentos judiciários como esses, se lidos com aguda atenção e sensibilidade, podem trazer-nos as perspectivas dos habitantes das senzalas sobre suas próprias experiências de vida em cativeiro.

\section{$* * *$}

Os documentos policiais e judiciários manuscritos confeccionados naquele verão de 1874 , hoje amare- lados pelo tempo decorrido, são custodiados pelo Arquivo Público do Estado do Rio Grande do Sul. O sólido prédio localizado no centro de Porto Alegre teve a construção de seu primeiro pavilhão iniciada em 1910 e concluída dois anos depois. Esse arquivo foi criado durante a gestão do Partido Republicano Rio-grandense, na longa administração do Presidente do Estado Borges de Medeiros, em 8 de março de 1906, o qual em sua mensagem para a Assembleia dos Representantes do estado no ano anterior, justificava-se:

\section{[...] a sua utilidade patenteia-se pelo próprio fim, que é o de coligir e conser- var tudo quanto possa interessar ao Rio Grande do Sul sob o ponto de vista da sua formação, do seu desenvolvimento político, da administração pública e, em suma, do progresso em todas as manifes- tações de atividades científica, literária e artística. $^{11}$}

Este prédio já centenário configura-se como um cenário adequado para guardar papéis que, mais do que suportes de práticas meramente burocráticas, são vestígios discursivos judiciários da dramaturgia do real, da beleza dos gestos, daquela plural sociedade oitocentista. Afinal, segundo Arlete Farge (2009, p. 49-50), "o sabor do arquivo se enraíza nesses encontros com silhuetas desfalecidas ou sublimes. Obscura beleza de tantas existências esclarecidas pelas palavras, confrontando-se com o outro, tão prisioneiras delas mesmas quanto desvencilhadas do tempo que as abriga".

Soa estranho falar de beleza do gesto quando tratamos de um ato tão cruel quanto o cometido por Leopoldina, mas a pretensa hediondez daquela atitude tão desumana, dissimula uma dimensão humana que nos atraiu desde a primeira leitura. Os vestígios retirados da rica peça judiciária montada para a investigação deste

\footnotetext{
${ }^{11}$ Arquivo Histórico do Rio Grande do Sul. Mensagem enviada à Assembleia dos Representantes do Estado do Rio Grande do Sul pelo Presidente Antônio Augusto Borges de Medeiros, em 20 de setembro de 1905. Porto Alegre, Oficinas tipográficas da Federação, 1905, p. 7.
} 
acontecimento, nos fornece indícios significativos para o entendimento das experiências familiares em cativeiro.

Leopoldina, ao que percebemos pelo processo, vivia na propriedade de Evaristo Antônio de Moraes com sua mãe e irmãos. Evidencia-se que, na opinião de Leopoldina, ela vivia uma situação constrangedora, desesperada não apenas pelos maus tratos recebidos da esposa de seu senhor, mas pela pressão psicológica da separação potencial de sua família, decorrência da eminente liberdade de sua mãe. Portanto, é preciso perceber a importância que os companheiros de Leopoldina, embora não se possa ter total acesso a estes sujeitos pelo processo, deveriam ter ao dividir este pesado fardo do cativeiro, uma forma de conseguir suportar todas as agruras diárias. Mas, talvez, ser incapaz de defender seu filho, tenha levado Leopoldina a tomar uma medida extrema.

Vamos tentar analisar algumas partes deste processo. No dia 4 de janeiro de 1874 aconteceu o primeiro interrogatório de Leopoldina:

Perguntada seu nome e idade? Respondeu chamar-se Leopoldina, idade não sabe. Perguntada de quem era escrava e quando cometeu o crime? Respondeu ser escrava de Evaristo Antônio de Moraes; e que cometeu o crime dia trinta e um de dezembro do ano próximo passado. Perguntada com que arma cometeu o crime e que idade tinha o filho dela interrogada? Respondeu que com uma faca que pertencia a um irmão dela interrogada, $e$ que seu filho tinha doze a treze anos de idade. [...] Perguntada se estava arrependida do crime que tinha cometido? Respondeu que sim. Perguntada se tem pessoas que sabem do mau trato que recebem em casa de seu senhor? Respondeu que sim, que são Miguel Martins Pinto, José Marques Ribeiro, Osmar Lafourcade, José Alves de Souza e todos os vizinhos. Perguntada como cometeu o crime? Respondeu que degolou-o com uma faca. E nada mais lhe sendo pergun- tado, assignou a rogo da interrogada Manoel Pereira da Silva, e as testemunhas Pedro Gaspar e João Henrique de Carvalho.

Leopoldina mantém esta versão até o final do processo. É interessante notar que segundo ela, muitos sabiam dos maus tratos que os escravizados recebiam na propriedade de Evaristo Antônio de Moraes, mais especificamente de sua esposa. Mas nos interrogatórios os depoimentos se mostram bem tímidos nessa questão, parecendo não querer evidenciar algum comprometimento com o futuro de Leopoldina ou, ainda, revelar alguma acusação que pudesse causar atritos nas redes de vizinhança, tão importantes nas realidades rurais. Em seu depoimento, José Francisco Pacheco ${ }^{12}$, quando indagado sobre Paulino, disse que "este se passava como livre, sendo sempre bem tratado". Em relação à condição jurídica de Paulino, reservaremos um espaço mais adiante, o que chamamos atenção no momento diz respeito ao confronto de depoimentos. A palavra daquela mulher escravizada Leopoldina, que foi enquadrada como louca durante o andamento do processo, dificilmente teria alguma chance contra a de homens livres, proprietários e senhores de cativos, com certeza testemunhas dignas de crédito, perante aquelas autoridades do período escravista.

Aos 31 dias do mês de janeiro, as autoridades interrogaram Leopoldina novamente, lhe perguntando se tinha alguma prova que demonstrasse ou justificasse sua inocência:

Respondeu que tem, e é o mau tratamento que lhe dava sua senhora, tratamento esse que é sabido pelos moradores de Vacacai, e que a obrigou a tomar a resolução de matar a seu filho e depois matar -se também, o que não fez porque não teve ânimo. Perguntado se é verdade que fosse ela interrogada a assassina de seu filho? Responde que é verdade, e que

\footnotetext{
${ }^{12}$ Depoimento de 31 jan. 1874. Casado, idade de sessenta e quatro anos, natural do Maranhão, residente no terceiro distrito d'este termo, com profissão de carpinteiro.
} 
cometeu tal crime por se ver crucificada em casa, e que sua intenção era matar-se depois de tirar a vida de seu filho, como já declarou, e que não fez por que lhe faltou ânimo.

Mesmo que naquele período histórico a escravidão fosse praticamente indefensável moralmente, dificilmente aquela mulher escravizada contaria com as simpatias dos profissionais do campo jurídico, principalmente tendo em vista o caráter repugnante do crime que cometera, para uma sociedade estruturada em laços e redes sócio familiares. Entretanto, dizer-se crucifica$d a$ em casa, denunciando os injustos tratos recebidos de sua senhora, podia atenuar o seu crime, jogando parte da culpa para o mau cativeiro em que se encontrava. Ainda neste depoimento, Leopoldina diz ter tentando suicidar-se na sequência, o que não pôde concluir pelo incidente com o rompimento da corda com que iria enforcar-se. A expressão crucificada remete ao discurso católico e mostra como a linguagem religiosa servia como modo de entendimento crítico e de exposição das duras realidades cotidianas. Por outro lado, insistir na tentativa frustrada de suicídio trás para a sua narrativa um conteúdo de arrependimento, também condizente com o imaginário católico da época.

O processo de organização das senzalas era extremamente complexo, talvez jamais consigamos compreendê-lo em sua forma total, mas o que sabemos até então diz respeito "as suas formas de acomodação". Uma vez que essas senzalas compreendiam um universo tão grande de indivíduos, sendo escravizados crioulos e africanos de diversas etnias, podemos pensar nesse espaço com um lugar de atrito, além da construção de solidariedades. O ingresso de um novo habitante poderia abalar essa acomodação, portanto, era muito caro a esses indivíduos que coabitavam a construção de laços diversos, de parentesco, de reciprocidade e solidariedade. $O$ espaço da senzala constituiu-se não apenas por atritos e solidariedades, mais dinâmico do que isto, prezou por uma eterna construção e reconstrução em sua forma organizacional (FLORENTINO; GOÉS, 1997, p. 31-37).

Slenes (1992, p. 49) nos ajuda a pensar esta questão da estrutura social das senzalas, segundo ele: "fazendeiros e autoridades do governo tinham um grande interesse prático em conhecer certos aspectos da cultura escrava para assegurar seu controle e evitar surpresas desagradáveis". Fazia parte da agenda das autoridades se manterem atentos e familiarizados com as possíveis rixas ou consonâncias entre as etnias que formavam as senzalas. Os desacordos entre crioulos e africanos ou entre africanos de etnias diferentes, poderia significar, aos senhores, certa brecha para controle destes indivíduos. Apesar dos habitantes das senzalas serem mestres da dissimulação, não podemos negar que houve um esforço muito grande por parte destes senhores para se infiltrarem na privacidade de seus trabalhadores escravizados.

A historiografia brasileira já explorou casos como este de Leopoldina, aos quais os pais se viam sem saída para livrar seus filhos do cativeiro e dos castigos que compunham o cenário cotidiano. Podemos destacar o caso que Manolo Florentino e José R. Goés trataram no prólogo em a Paz das Senzalas (1997, p. 15), a introdução é tão emocionante quanto o caso, em suas palavras:

Diz uma sura do Corão que Deus só imporá a cada alma o que ela puder suportar. Oxalá fosse sempre assim e cada criatura tivesse o seu quinhão de sofrimento ministrado, com parcimônia, por um Criador afeito ao cálculo comedido. Não foi o que aconteceu, contudo, a Marcelino Francisco Inácio e aos seus. Talvez porque ele e seus filhos fossem mais criação da cobiça dos homens do que obra da inspiração dos deuses. Quem pode saber o que é do homem e o que é de Deus? O certo é que foi nos Campos dos Goitacazes, por volta do meio-dia de 30 de junho de 1847, que o desespero fêlo encontrar-se consigo próprio para 
uma peleja que a todos no lugar horrorizou. A história de Marcelino é uma história de horror e começara antes daquele dia, em data imprecisa.

O caso de Marcelino chocou as autoridades, que se mostraram incrédulas, mais uma vez, com a possibilidade de um pai ter matado seus filhos para livrá-los do cativeiro e lhe indagaram: "e tu tiveste ânimo de matar teus filhos?". Muitos destes pais, ao serem levados a júri, serão enquadrados em casos de loucura, ou terão seus atos justificados através da influência do uso de alguma bebida forte, pois mesmo em uma sociedade altamente violenta, em um sistema como o da escravidão, em que a agressão física fazia parte da rotina destes sujeitos, seria inconcebível que um pai tivesse coragem para tal ato. Devemos salientar, obviamente, que o sistema escravista não pôde perdurar tanto tempo apoiado unicamente na violência ${ }^{13}$. Aos escravizados era designada uma condição quase animalesca, mais coisas do que sujeitos, estes indivíduos não poderiam responder por si em diversos casos, mas surpreendentemente tirar a vida do próprio filho parecia algo que nem mesmo um sujeito classificado entre coisa e animal, seria capaz de fazer. Desta forma, não só se atribui humanidade ao cativo, já que se aceita que ele perdeu a razão, mas também parece estratégico este diagnóstico, por isentar o próprio sistema escravista da crueldade de separar famílias.

Podemos, ainda, citar o caso de Ana Blauth, uma mãe experiente, que já havia dado a luz a 10 crianças, das quais apenas 5 sobreviveram ao parto e vingaram aos primeiros anos de vida. Foi em seu décimo primeiro filho que deu a luz, na propriedade de seu exsenhor e como nas demais vezes sem ajuda de parteira, a um bebê natimorto. Não tardou para que o caso despertasse a atenção das autoridades e Ana fosse indiciada por infanticídio, no ano de 1885, em São Leopoldo/ RS. Alguns detalhes desse caso são importantes a ser mencionados, primeiro, que quando os peritos desenterraram o cadáver do filho de Ana Blauth, se deparam com um bebê de cor branca e cabelos cacheados, indicando a relação de Ana com outro parceiro, provavelmente branco, mas este parceiro não foi revelado ao longo do processo. Ademais a justificativa que as autoridades dão para absolver Ana são, como se previa, preconceituosas:

Não é provável a sua existência [de culpa], porque sendo a ré mãe de dez filhos, entrando neste número os que nasceram mortos, nenhuma razão pode existir para supor-se o crime, não só porque a sua condição de escrava e ex-escrava colocaa em posição ínfima, na qual não pode existir os sentimentos de honra e vergonha à vista do crescido número de filhos naturais, e por esse motivo exclui a possibilidade de matar o filho para evitar a vergonha e a desonra. ${ }^{14}$

Portanto, egressa do cativeiro, mas ainda presa ao ex-senhor por uma alforria condicional à prestação de anos de serviços, Ana não seria capaz de ter sentimentos como honra e vergonha. Num argumento obviamente racializado, as autoridades judiciárias inocentam esta mulher negra, depreciando a sua possibilidade de sentir carinho pelo próprio filho e pudor com relação a sociedade. Manipulando variáveis como condição escrava, raça e gênero, esses sisudos bacharéis em suas verborragias discursivas, representavam Ana apenas como um ventre reprodutor, gerador de novas vidas, mas não de sentimentos de maternidade.

\footnotetext{
${ }^{13}$ As autoridades se preocupavam, também, em como a violência extrema poderia estimular uma revolta incontrolável ao apresentar um "desestímulo ao serviço". Desta forma, podemos pensar em como as festas, batuques e reuniões eram ministradas em doses homeopáticas pelos senhores, nem totalmente negadas, mas vistas como um incentivo ao trabalho e a paz no cativeiro.

${ }^{14}$ Este caso bem como a citação do processo foram retirados do capítulo: MOREIRA, P. MÜGGE, M. Maternidades em cativeiro: o caso de Ana Blauth, ex-escrava de Nicolau Blauth. in: MOREIRA; MÜGGE. Histórias de escravos e senhores em uma região de imigração europeia. São Leopoldo: Oikos, 2014.
} 
Mas voltemos ao processo de Leopoldina. A ré declara que no dia que tomara a decisão de matar a Paulino e a si própria, sua senhora a teria queimado com fogo, definindo um ambiente de violência feminina marcado pelo espaço doméstico de convívio, além de também maltratar seu filho, que, segundo ela, sequer recebia roupas. Ainda declara que sua senhora tinha muito ciúme, segundo ela infundado. Em seu interrogatório, Leopoldina apontou esse fato quando perguntada por qual motivo havia cometido "tão horrendo" crime, respondendo que "ela, seu filho e sua mãe e todos os escravos eram muito mau tratados pela mulher de seu senhor, tanto assim que no dia que ela cometeu o crime sua senhora queimou-a com fogo". Leopoldina ainda depôs declarando que a decisão de matar seu filho não teria sido premeditada, como talvez pudessem pensar as autoridades:

Perguntado a que horas cometeu o crime, e desde quando pensava em matar a seu filho? Respondeu que foi depois de meio-dia, hora essa em que pela primeira vez the veio no pensamento semelhante ideia e isto pelos maus tratos que nesse dia lhe infligiu sua senhora, a ponto de queimá-la com um tição de fogo e pelo que ela interrogada animou-se a pedir a sua senhora nesse dia carta de venda, sendo em resposta de sua senhora que não a vendia, que havia de maltratá-la até matá-la, e que além disso sua senhora tinha ciúmes infundado dela interrogada; por isso, por se ver em desespero é que tomara nesse mesmo dia a resolução de morrer com seu filho, assassinando a este.

Não são raros os casos de ciúmes das senhoras com suas escravas, principalmente por sabermos ter existido um número grande de casos de infidelidade no período colonial e imperial brasileiro. Elione Guimarães, estudando os casos de inventários post-mortem de senhores no Vale da Paraíba mineiro, identifica uma série de senhores reconhecendo filhos entre seus escra- vizados na partilha de bens. (GUIMARÃES, 2009).

Normalmente as senhoras são acusadas de agredir mulheres escravizadas e seus filhos, o que denota que elas tinham autoridade privilegiada no espaço privado dos lares e das cozinhas. As próprias torturas infligidas são praticadas por instrumentos do cotidiano doméstico, como o tição com que a senhora queimou a Leopoldina, provavelmente retirado do fogão da casa.

Outro detalhe que nos chama atenção neste depoimento, é que Leopoldina diz ter pedido a sua senhora que a vendesse, e esta se negou. Era comum que escravos pedissem sua venda quando entendiam que esta poderia significar uma melhoria de vida. Essa relativa autonomia é interessante, pois mesmo que o escravo pudesse opinar em relação a venda, a última palavra sempre seria a do senhor, a não ser que em algum momento, ou por algum motivo, o Estado se intrometesse nessa relação privada.

A morte de um senhor, a partilha de bens ou mesmo uma mudança dentro da casa senhorial poderia afetar diretamente os cativos da propriedade ${ }^{15}$. A angústia de ter a família e os companheiros separados era algo presente nas senzalas, contra a qual os cativos manifestaram diversas formas de resistência e capacidade de negociação. Sidney Chalhoub (1990) explorou esses casos em que companheiros e familiares são separados com a intensificação do tráfico interprovincial, em um fluxo acentuado para o sudeste cafeeiro. Estes escravizados eram, em suma, cativos já enraizados, muitos desses crioulos que conheciam e conviviam em família, em uma teia de relacionamentos já estabelecida. São esses sujeitos que serão conhecidos por sua rebeldia, uma vez que muitos se rebelam contra sua própria venda para as fazendas de café. É totalmente compreensivo que se rebelassem, eram seres-humanos arrancados de

\footnotetext{
${ }^{15}$ Cristiany M. Rocha (2006) exemplifica bem esta questão do destino incerto das famílias escravas em seu trabalho.
} 
suas famílias para um lugar totalmente desconhecido, onde teriam que lutar por uma nova acomodação dentro daquelas senzalas, com indivíduos totalmente desconhecidos dos quais estavam habituados. A (re) acomodação necessária com a chegada de novos habitantes às senzalas naquele momento foi testada novamente, no caso desses trabalhadores escravizados vítimas do fluxo interprovincial.

Não podemos inferir o motivo do ciúme da senhora em relação a Leopoldina, mas podemos considerar que, talvez, o cerne fosse a infidelidade de Evaristo ou quem sabe aquelas mulheres - a senhora e a cria da casa - estivessem acomodando ou ajustando a relação de poder na esfera privada-doméstica. Leopoldina movia-se com relativa autonomia e seu filho, ao que parece, não era mais cativo, configurando-se ter obtido uma série de pequenas, porém relevantes, conquistas. Convenhamos que assuntos relacionados a família, ao afeto, a autonomia, não podem ser simplesmente descartados. Por eles compensa, na experiência histórica humana, matar e morrer.

Procuramos cruzar esta peça judiciária com os documentos eclesiásticos e por isso frequentamos o Arquivo da Cúria Metropolitana de Cachoeira do Sul, no qual encontramos registros batismais de escravos, de 1799 a 1859 . Fichamos um total de 2.480 momentos em que crianças saídas de ventre cativo receberam os santos óleos, que permitiam o acesso á cristandade. Infelizmente, e de uma maneira brusca e até o momento sem qualquer explicação, os padres locais pararam de registrar os batismos de escravos. Isso ocorreu em novembro de 1859 e fez com que o terceiro e último códice localizado parasse de ser preenchido na página 43, ficando o restante das folhas em branco.
Assim, não tivemos acesso ao registro de batismo de Paulino. Mas existem grandes chances de que se fosse Paulino filho do senhor, mesmo que isso não estivesse designado no assento. Devido a ausência desse registro não tivemos acesso a informações mais específicas sobre ele, como por exemplo, quem poderiam ser seus padrinhos, pai, ou se tratava-se de um caso de filho "natural". O número de filhos naturais entre a população cativa é bem grande, no entanto, isto não significava que o pai ou mãe não fossem conhecidos ou que não convivessem em proximidade, mas da existência de relações afetivas consensuais e da matricentralidade.

O caso de Leopoldina deve ser visto como uma mina de informações sobre práticas cotidianas de ação e negociação, que por várias vezes acabaram em tragédias existenciais. O documento judiciário nos abre uma janela possível de entendimento àquela realidade, fornecendo-nos informações fragmentadas, mas que nos estimulam a um exercício de imaginação histórica. Não temos acesso a outras ações ou motivações de Leopoldina, mas sabemos o que a morte de dois cativos poderia significar para o proprietário ${ }^{16}$. Paulino, que tinha em torno de 13 anos, se encaminhava para sua idade mais produtiva, um crioulo que poderia ter sido desde novo treinado nos ofícios do trabalho rural. Leopoldina ainda era jovem, provavelmente não havia chegado aos 30 anos, o que indica ser uma mulher escravizada no auge de sua capacidade produtiva e reprodutiva. Ela apresenta a si mesma nos interrogatórios como dedicada a plural área dos serviços domésticos. Para Evaristo, no ano de 1874, em que os escravos já eram mais caros e escassos com o fim do trafico transatlântico e com o movimento de tráfico interprovincial para o sudeste brasileiro, podemos imaginar o quão grande foi o seu

\footnotetext{
${ }^{16}$ Provavelmente Evaristo era mais um exemplo de um pequeno ou médio senhor de escravos, mas isto é apenas uma intuição partindo das características de posse no Rio Grande de São Pedro e do restante do Império. Para mais informações sobre o perfil da posse escrava na província, ver: GOMES (2012).
} 
prejuízo. Antes do término do processo, Leopoldina foi alforriada, aparentemente seu senhor preferiu abrir mão de sua trabalhadora compulsória a ter mais encargos com as custas do processo.

Em 1882, no litoral norte gaúcho, na Vila de Conceição do Arroio, o angolano Francisco, com 50 anos e cozinheiro, escravizado por Bernardina Joaquina Osório, foi processado por ter assassinado Manoel, cativo de Ana Tomásia de Jesus. Eles estavam matando o bixo - tomando cachaça - em uma venda, quando na saída da mesma tiveram uma disputa de palavras e deu -se a cena de sangue. Parece que ambos, agressor e ofendido, eram amigos, mas disputavam os encantos de uma mesma mulher, a parda Narcisa, que enganava a ambos. Na sequência do processo, o réu Francisco recebe carta de alforria de sua senhora, graciosamente, ou seja, sem ônus ou condição alguma. Na reunião do júri, praticamente seis meses depois do crime, o réu usa como argumento de defesa ser estimado pelos senhores, ao que rebate o Juiz de Direito, indagando que se isso era correto porque "o abandonaram sem lhe constituir um defensor?". Ao que responde o angolano Francisco: "que depois de estar preso ouviu dizer pela rua que sua senhora declarara que sendo ele um negro velho e quebrado e que pouco podia viver, e estando entregue a justiça, não queria mais gastar dinheiro para constituir defensor". A graciosa alforria estava assim explicada e o liberto mudou-se da senzala de sua senhora para a cadeia, sendo condenado a 12 anos de prisão com trabalho. ${ }^{17}$

Percebemos algumas contradições em relação aos depoimentos no que diz respeito a suposta liberdade de Paulino. As testemunhas pareciam confusas com relação ao seu status, não sendo consenso se ele era ainda escravizado ou já obtivera a liberdade. Certamente
Paulino nascera do ventre escravo de Leopoldina e pelo menos nos cartórios locais não localizamos o registro de sua carta de liberdade, que, se foi concedida realmente, foi de maneira oral. A maneira como Paulino vivia não deixava claro o seu status, algumas testemunhas o reconheciam como liberto, outras não sabiam dizer, incluindo a sua própria mãe. Leopoldina foi interrogada e perguntaram-lhe que idade que tinha seu filho e se ele era livre ou escravo, ao que ela respondeu: "que não sabe a idade, mas supõe ser a que disseram as testemunhas; e que não sabe se ele era livre ou escravo, porque nunca ouviu falar em casa". Isso nos leva a pensar sobre como a liberdade desses cativos era frágil, vivendo numa fronteira tênue entre escravidão e liberdade.

Mas nossa busca nos tabelionatos de Cachoeira não foi inútil, pois encontramos a carta de alforria da mãe de Leopoldina, que como percebemos na narrativa que fizemos dos acontecimentos de dezembro de 1873 , foi um dos estopins das desgraças ocorridas. A mãe de Leopoldina chamava-se Rosa, tinha mais de 50 anos de idade, era descrita como preta e crioula. O senhor Evaristo Antônio Moraes passou a carta de alforria em 8 de janeiro de 1874 e registrou-a em cartório no mesmo $\operatorname{dia}^{18}$. Tratou-se de uma alforria paga, sendo os recursos (400 mil réis) entregues por Miguel Martins Pinto, com "a condição dela ausentar-se deste terceiro Distrito". Essa condição certamente foi um desdobramento do assassinato cometido por Leopoldina e com isso fica claro que aquela família escrava estava em confronto com a família senhorial.

A crioula Rosa herdou a cor preta de sua ancestralidade africana, já que era filha natural de Maria, africana da Guiné. Ela recebeu os santos óleos do batismo na Igreja Nossa Senhora da Conceição da Cachoeira em 16.04.1826, tendo nascido em 2 de fevereiro daque-

\footnotetext{
${ }^{17}$ APERS - Comarca de Santo Antonio da Patrulha, Vila de Osório, Caixa 278, processo 567.

${ }^{18}$ Arquivo Público do Estado do RS - $2^{\circ}$ Tabelionato de Cachoeira do Sul, Livros Notariais de Transmissões e Notas n 13 - 1873 a 1874 , folha $42 \mathrm{v}$.
} 
le mesmo ano. Pertencia ao sogro de Evaristo, Santos Martins Pinto, e o padre registrou que sua paternidade era incógnita e os padrinhos foram Procópio José da Silva e Leocádia Maria dos Anjos. O ritual católico foi ministrado pelo padre Inácio Francisco Xavier dos Santos. $^{19}$

Vasculhando nos documentos cartoriais encontramos o inventário post-mortem do Capitão Santos Martins Pinto. Não sabemos exatamente quando ele morreu, mas a sua viúva abriu o inventário em 1843 , quando já estava casada, em segundas núpcias, com Jesuíno Antônio de Moraes ${ }^{20}$. O casal tinha, na época, dez filhos, sendo quatro menores ${ }^{21}$. Dois dos herdeiros nos interessam especialmente, o mais velho, Miguel, que depois assumirá o segundo nome e o sobrenome paternos e se tornará fazendeiro. Miguel Martins Pinto foi citado por Leopoldina como testemunha dos martírios de que era vítima ${ }^{22}$. Além disso, foi ele que entregou os 400 mil réis para pagar a alforria da mãe de Leopoldina, Rosa, quantia que não temos como saber se Miguel fornecera a Rosa ou apenas era o guardião de seu pecúlio. O outro herdeiro que nos chamou a atenção foi Joaquina, que era casada com Evaristo Antonio de Moraes. Ainda que Joaquina tenha sido senhora de Leopoldina e sua mãe durante muito tempo, 6 anos antes do crime ela faleceu (1868) e, portanto, a senhora a qual Leopoldina direciona os maus tratos foi uma segunda companheira do senhor Evaristo, infelizmente ainda não temos informações sobre esta "nova senhora”.

Os herdeiros do Capitão Santos Martins Pinto compartilharam um monte-mor de 46:911\$240 réis, ficando para a viúva a meação de 23:455\$620 réis. Ele tinha campos no Faxinal e na Tapera, uma estância com benfeitorias, gado ${ }^{23}$ e 26 trabalhadores escravizados, sendo 16 homens e 10 mulheres, 6 africanos ${ }^{24}$ e o restante crioulos. Sete eram crianças de até 11 anos. Os únicos que tinham as suas profissões explicitadas eram 3 campeiros (todos crioulos), uma cozinheira (africana) e uma costureira (crioula).

A existência das crianças e outros indícios documentais, incluindo o caso do filicídio cometido por Leopoldina, faz-nos pensar não num grupo marcado pela anomia, mas uma comunidade amalgamada por laços diversos de parentesco. Às 8 horas da manhã do dia 20 de outubro de 1830 casaram na Igreja de Nossa Senhora da Conceição da Cachoeira os africanos José e Josefa, escravizados por Santos Martins Pinto, ambos de nação Guiné. Seis meses antes, em 28-04-1830, foi batizado no mesmo templo santo, Caetano, nascido em 10.02.1830, filho natural de Josefa. Em 25.04.1835 recebeu os santos óleos Patrício, nascido em 02.08.1834, filho legítimo dos africanos da costa Josefa e José. Foram padrinhos alguns parceiros de cativeiro: Benedito (pardo, liberto) e Laurinda (cativa de Francisco Rodrigues). ${ }^{25}$

\footnotetext{
${ }^{19}$ Arquivo da Cúria Metropolitana de Cachoeira do Sul, Livro 1º de Batismos de Escravos de Cachoeira (1799/1842).

${ }^{20}$ Jesuíno e Anacleta casaram na Igreja de Nossa Senhora da Conceição da Cachoeira às 8 horas da noite do dia 7 de dezembro de 1842 . Ele era filho legítimo de Salvador Antônio de Moraes, já falecido, e de Inácia Maria dos Santos, e era natural desta freguesia. Anacleta era descrita somente como viúva de Santos Martins Pinto. (Livro $3^{\circ}$ de Assentos de Casamentos de Cachoeira, folha 135). APERS - Juízo de Órfãos do termo de Cachoeira, Comarca de Rio Pardo, inventário $\mathrm{n}^{\circ}$ 103, inventariado: Capitão Santos Martins Pinto, inventariante: Anacleta Maria Dos Anjos, data do processo: 1843.

${ }^{21}$ Participaram da divisão do espólio os seguintes filhos: Miguel (solteiro, 22 anos), Santos (solteiro, 19 anos; soldado do $3^{\circ}$ Corpo de Linha), Martiniano (menor, 8 anos), Bonifácio (menor, 6 anos), Joaquina Maria da Conceição (casada com Evaristo Antônio de Moraes), Leocádia (casada com Antônio Alves de Oliveira), Maria (solteira, 25 anos), Ana (solteira, 15 anos), Cesária (solteira, 12 anos) e Fermina (menor, 5 anos).

${ }^{22}$ Em 1879 o fazendeiro Miguel Martins Pinto ainda residia no $3^{\circ}$ distrito de Cachoeira, quando denunciou alguns vizinhos por roubo de gado e madeiras de sua propriedade. APERS - Juízo Municipal da Cachoeira, Processo crime 3226, Réu: Feliciano da Rosa Garcia e outros, Vítima: Miguel Martins Pinto, data: 1879, Cachoeira, Comarca de Rio Pardo.

${ }^{23} \mathrm{O}$ rebanho era assim constituído: 15 bois mansos (150\$ réis), 400 reses mansas de criar ( 2 contos de réis), 600 reses de rodeio xucras (2:400\$), 3.000 reses alçadas (12:000\$), 44 cavalos mansos (352\$000), 255 éguas xucras (816\$000), 1 macho xucro (10\$000), e 80 ovelhas (51\$200).

${ }^{24}$ Os indivíduos que haviam passado pessoalmente pela diáspora transatlântica eram: os minas Américo e Vicência ( 30 anos), os da costa João (40 anos), José Pequeno (45 anos) e Domingos (30 anos) e a africana Josefa (casada, com 46 anos e cozinheira).

${ }^{25}$ AHCMCS - Livro de Casamentos no 3 (1823-1849), folha 66.
} 
Entre os escravos arrolados encontramos a mãe de Leopoldina, Rosa, então com 15 anos de idade e avaliada por 600 mil réis. Entre as declarações feitas pela inventariante, está a de que o co-herdeiro Evaristo “já tem em seu poder a escrava crioula Rosa”. Não sabemos se Rosa já estava com Evaristo por ter sido o dote recebido quando de seu casamento com Joaquina. Isso talvez nos dê pistas sobre a relação íntima entre Rosa e sua filha Leopoldina com a senhora, já que ela deve ter sido importantíssima na nova vida de casada daquela jovem mulher. Quem sabe Rosa e sua filha Leopoldina tivessem adquirido importância na dinâmica de controle e gestão daquela unidade doméstica, o que poderia incitar, também, conflitos.

Daquela partilha de 1843 Joaquina e Evaristo levaram $2.345 \$ 562$ réis, sendo esta quantia composta dos cativos Zeferino (140\$), Antônio (66\$666), Rosa (600\$) e José (250\$), alguns animais (8 reses xucras, 7 reses mansas, um animal cavalar, já velho, 20 reses xucras, 8 reses mansas, 80 reses de gado alçado), parcelas de terra e partes de algumas dívidas passivas.

Chamamos aqui atenção, para outro detalhe. $\mathrm{Na}$ primeira página do processo Leopoldina é apresentada como crioula, nas demais ela é constantemente referida como preta. Leopoldina era crioula, nascida em Cachoeira, inclusive convivia com sua mãe. Pode ser que Leopoldina se destacasse por uma tez mais escura, mas a designação de cor "preta" normalmente está associada a africanos ou a condição jurídica de escravizado. Mesmo para os libertos africanos esta cor poderia ser associada a um insulto. A análise de cor é um campo amplo dentro da historiografia, ao qual não pretendemos nos aprofundar, mas não podemos deixar de pensar que este detalhe talvez fosse uma forma de reforçar a posição subalterna de Leopoldina durante o processo ou talvez indício da africanidade herdada.

\section{Considerações finais}

Em 1874, na Vila de Cachoeira/RS, as autoridades quedavam-se incrédulas já que uma mulher escravizada de nome Leopoldina havia cometido filicídio. Não conseguiam acreditar como uma mãe poderia ser capaz de fazer isso ao próprio filho. $\mathrm{O}$ fez, ainda, com uma faca que havia pegado emprestada de um irmãozinho seu e provavelmente moravam na mesma propriedade. Tratava-se de uma família constituída dentro do cativeiro, Leopoldina também vivia com sua mãe na propriedade de Evaristo Antônio de Moraes, mas quis o destino que em breve sua mãe fosse libertada. A motivação do crime de Leopoldina era, além da eminente alforria de sua mãe e da eventual separação daquele núcleo familiar, os maus tratos que recebia de sua senhora.

Com a análise deste processo crime tentamos reconstruir alguns aspectos da vida familiar e das demais vivências daquela mulher escravizada, tomando como base uma bibliografia que tenta compreender as nuances das famílias constituídas dentro do cativeiro. Aspectos como liberdade, violência, resistência, negociações e cor, puderam ser vistos. Não temos acesso aos mais minuciosos detalhes da vida que Leopoldina levou na companhia dos irmãos e da mãe. No entanto, sabemos que este crime abalou, não somente as autoridades locais, mas de alguma forma contribuiu para o debate ideológico da época que custava a admitir que uma mãe fosse capaz de tal ato, ao mesmo tempo em que via no escravo um indivíduo desprovido, por natureza, de humanidade. Nos parece, além disso, que um ato desumano desses ajudava a solapar as bases enfraquecidas da instituição escravista, mostrando a violência inerente que comportava.

Leopoldina, como dito anteriormente, foi enquadrada em um caso de loucura, que explicaria o assassinato de seu filho. No entanto, embora com esta tese a ré 
tenha sido absolvida, o Juiz de Direito Augusto Cezar de Medeiros, aos dez dias do mês de junho, recorreu da decisão, com a seguinte justificativa:

Fiel ao cumprimento de meus deveres eu não podia deixar passar em julgamento essa decisão em virtude da qual foi a ré absolvida, por me parecer contrária a evidencia resultante das provas dos autos $e$ dos debates perante o júri. Com efeito, se nos paroxismos de uma paixão violenta há alguma perturbação da razão, como dizem os médicos legistas, raras vezes chega isso ao estado de loucura, e comparar sempre as paixões à loucura é animar o crime por meio da impunidade. Além disto, a loucura transitória é um facto psicológico posto em dúvida e contestada pela maior parte dos médicos. Ora, ainda admitindo como certo que a ré fosse maltratada com rigorosos castigos por sua ex-senhora, pelos motivos alegados nos seus interrogatórios, era isso um fato de mais ou menos permanência, que se remontava a época muito anterior ao delito, e com o qual já ela estava acostumada; não era um facto ocasional e imprevisto, que pudesse produzir tão súbita e violenta paixão a ponto de lhe obscurecer inteiramente a razão e tirar-lhe o conhecimento do mal e a intenção de o praticar. Ao contrário, porém, é o que consta dos autos, a ré teve pleno conhecimento do mal que ia praticar, combinou perfeitamente o seu plano, e executou-o procurando depois escapar a ação da justiça por meio da histeria, que inventara de ter sido seu filho assassinado por uns malfeitores, aos quais ela pôde escapar milagrosamente: Se a ré era injusta e barbaramente maltratada por sua ex-senhora, o que se não provem outro era o meio de que devia lançar mão, era o recorrer a autoridade para garanti-la contra os excessos de seus senhores. Mas o que parece mais presumivel, é que ela fora impelida pelo [desejo] da vingança contra seus senhores, na pessoa de seu filho, que eles estimavam tanto que já o haviam libertado gratuitamente, disso tem havido infelizmente vários exemplos.

Nesta etapa do processo, já passados seis meses do crime cometido, podemos imaginar o quanto Leopoldina já deveria estar cansada das idas e vindas aos interrogatórios. Para o Juiz de Direito, usar o argumento de loucura seria superficial demais, por se tratar de um estado de loucura momentâneo que não poderia ser apurado pelos médicos. Ainda para as autoridades, os maus tratos recebidos também não justificavam o delito, pois já deveria estar acostumada a eles. Desse modo, a decisão de matar seu filho não poderia estar embasada no acúmulo de pressão ao qual Leopoldina cercava-se. Para tanto, caso Leopoldina de fato vivesse em estado tão calamitoso, era seu dever procurar as autoridades para que tomassem providências, as mesmas autoridades que agora julgavam o crime de Leopoldina e diziam que sua condição deveria a ter feito aceitar os maus tratos. Por fim, o juiz insinua que Leopoldina, movida pela vingança a seus senhores, matou Paulino com o único fim de afetá-los, pois aparentemente o menino maltratado era muito querido pela Casa Grande. Leopoldina deveria manter-se a única culpada da história, e seus senhores os lesados, afinal, como dito anteriormente, Paulino representava uma perda muito grande em termos econômicos, e por fim, caso a situação realmente fosse tão ruim, cabia Leopoldina recorrer às autoridades.

Leopoldina foi uma das muitas escravas que cometeram infanticídio para livrar seus filhos do cativeiro, assim, é importante pensar neste ato em sua forma mais ampla. O que fizemos aqui foi uma análise inicial da Vila de Cachoeira e da família escrava a partir deste processo. Podemos ver esta fonte como uma janela para as angústias da família escrava e de suas formas de resistência diárias, bem como um fragmento dos ideais e concepções jurídicas dos últimos anos de escravidão no Império.

Em um último ato de carinho por seu filho, podemos imaginar Leopoldina colocando gentilmente seu vestido sobre o corpo já sem vida de Paulino. Embora tenha sido absolvida através da tese de loucura, após a interferência do Juiz de Direito descrita acima, que recorreu da decisão e instaurou um novo julgamento, ela 
foi sujeita a um novo julgamento e sentenciada culpada e pena de 20 anos de galés pelo crime.

Óbvio que a figura do senhor, razoavelmente esmaecida neste documento judiciário, não pode nunca ser desprezada em sua posição de poder. Seria ingenuidade nossa pensá-lo distante dos desdobramentos desta rotina judiciária, que poderia privá-lo de uma valorizada propriedade. Leopoldina era uma trabalhadora doméstica em idade produtiva e reprodutiva, e mesmo que a lei de 1871 tenha alforriado o ventre escravo, o trabalho dos ingênuos interessava, e muito, aos senhores
(PERUSSATO, 2010; MOREIRA, 2013). Personalizar as agressões sofridas por Leopoldina em sua "nova" senhora, ou pelo menos focar a esposa do senhor como ponto nodal das violências cometidas, talvez fizesse parte de uma estratégia discursiva de isentar o patriarca, jogando as violências sob a responsabilidade da figura senhorial feminina (cuja natureza a tornava habitualmente passível de ser considerada instável e descontrolada). O senhor, assim, isentava-se de praticar agressões descabidas, excessivas, o que o faria passar entre vizinhos e autoridades como um administrador deficiente, um mau senhor.

\section{Abreviaturas:}

AHCMCS - Arquivo da Cúria Metropolitana de Cachoeira do Sul;

AHRS - Arquivo Histórico do Rio Grande do Sul;

ANRJ- Arquivo Nacional - Rio de Janeiro;

APERS - Arquivo Público do Estado do Rio Grande do Sul;

BNRJ - Biblioteca Nacional do Rio de Janeiro;

PNSC-SL - Paróquia Nossa Senhora da Conceição de São Leopoldo;

\section{Referências bibliográficas:}

ARAÚJO. Thiago Leitão. de. Novos Dados sobre a Escravidão na Província de São Pedro. $5^{\circ}$ Encontro de Escravidão e Liberdade no Brasil Meridional. Porto Alegre, Universidade Federal do Rio Grande do Sul, 2011.

BLOCH, Marc. Apologia da História ou O Ofício de Historiador. Rio de Janeiro: Zahar, 2001.

CERTEAU, Michel de. A escrita da história. Rio de Janeiro: Forense-Universitária, 1982.

CHALHOUB, Sidney. Visões da liberdade: uma história das últimas décadas da escravidão na Corte. São Paulo: Companhia das Letras, 2011.

FAGUNDES, Rosicler Maria Righi. Esfaqueamento no Púlpito: o comércio e suas elites em Cachoeira do Sul na segunda metade do séc. XIX (1845-1865). PPGH/Universidade do Vale do Rio dos Sinos, 2009. [Dissertação de Mestrado]

FARGE, Arlette. O sabor do arquivo. São Paulo: Edusp, 2009.

FLORENTINO, Manolo; GÓES, José Roberto. A Paz das senzalas: famílias escravas e tráfico atlântico, Rio de Janeiro, 1790-1850. Rio de Janeiro: Civilização Brasileira, 1997.

FORTES, Amyr Borges; WAGNER, João Baptista Santiago. História administrativa, judiciária e eclesiástica do Rio Grande do Sul. Porto Alegre: Globo, 1963.

FUNDAÇÃo DE ECONOMIA E ESTATÍSTICA. De Província de São Pedro a Estado do Rio Grande do Sul. Censos do RS: 1803-1950. Porto Alegre: FEE, 1981. 
GINZBURG, Carlo. Provas e Possibilidades à margem de "Il ritorno de Martin Guerre", de Natalie Davis. A Micro -História e Outros Ensaios. Lisboa: DIFEL; Rio de Janeiro: Bertrand Brasil, 1991.

GOMES, Luciano Costa. Uma cidade negra: escravidão, estrutura econômico-demográfica e diferenciação social na formação de Porto Alegre, 1772 - 1802. Porto Alegre: PPG-História/UFRGS, 2012. [Dissertação de mestrado].

GUIMARÃES, Elione. Terra de Preto. Usos e ocupação da terra por escravos e libertos (Vale da Paraíba mineiro, 1850-1920). Niterói: Editora UFF, 2009.

GUTERRES, Letícia Batistella Silveira. Escravidão, Família e Compadrio ao Sul do Império do Brasil: Santa Maria (1844-1882). Rio de Janeiro, PPGH-Universidade Federal do Rio de Janeiro, 2013. [Tese de doutorado]

MOREIRA, Paulo R. Staudt. Os cativos e os homens de bem: experiências negras no espaço urbano: Porto Alegre, 1858-1888. Porto Alegre, EST, 2003.

MOREIRA, Paulo R. Staudt. Etnicidade e Liberdade: As nações africanas e suas práticas de alforria. Ciências e Letras (Porto Alegre), v. 44, p. 167-186, 2008.

MOREIRA; MÜGGE. Histórias de escravos e senhores em uma região de imigração europeia. São Leopoldo: Oikos, 2014.

MOREIRA, Paulo Roberto Staudt. Ingênuas Mortes Negras: Doenças e Óbitos dos Filhos do Ventre Livre (Porto Alegre, $R S$ - 1871/1888). Revista Territórios \& Fronteiras. Cuiabá, vol. 6, n. 2, jul.-dez., 2013.

PERUSSATO, Melina. K. Como se de ventre livre nascesse. Experiências de cativeiro, parentesco, emancipação e liberdade nos derradeiros anos da escravidão. Rio Pardo/RS. 1860-1888. Dissertação de Mestrado - UNISINOS, 2010 .

ROCHA, Cristiany M. A morte do senhor e o destino das famílias escravas nas partilhas. Campinas, século XIX. Revista Brasileira de História, v. 26, p. 175-192, 2006.

SCHWARTZ, Stuart. A historiografia recente da escravidão brasileira. In: SCHWARTZ, Stuart. Escravos, Roceiros e Rebeldes. São Paulo: EDUSC, 2001.

SLENES, Robert. Na senzala, uma flor. Esperanças e recordações na formação da família escrava - Brasil Sudeste, século XIX. Rio de Janeiro: Nova Fronteira, 1999.

SLENES, R. Malungu, Ngoma Vem!: África coberta e descoberta do Brasil. REVISTA USP, São Paulo, v. 12, p. 48-67, 1992.

SÔNEGO, Aline. "Sob a condição que continue em nossa companhia": as décadas finais da escravidão e a transição para o trabalho livre em um município Rio-grandense (Cachoeira 1871/1889). Passo Fundo, PPGHUniversidade de Passo Fundo, 2011. [Dissertação de Mestrado]

OLIVEIRA, Renata Saldanha. Cativos Julgados: Experiências Sociais Escravas de Autonomia, Sobrevivência e Liberdade em Cachoeira do Sul na Segunda Metade do Século XIX. Santa Maria, PPGH/Universidade Federal de Santa Maria, 2013. [Dissertação de Mestrado]

VENANCIO, Renato Pinto. Cativos do Reino: a circulação de escravos entre Portugal e Brasil, séculos 18 e 19. São Paulo: Alameda, 2012.

Submissão: 22/05/2016 Aceite: $25 / 10 / 2016$ 